\title{
Globalisation and Chinese Knowledge Diaspora: An Australian Case Study
}

\author{
Rui Yang \\ Faculty of Education \\ University of Hong Kong \\ Pokfulam Road, Hong Kong \\ Phone: 852 28578524, Fax: 85228585649 \\ Email: yangrui@hkucc.hku.hk \\ $\&$ \\ Fang-fang Qiu \\ St Peter's College \\ St Peters, SA 5069, Australia \\ Phone: 00618 83623451, Fax: 0061883632239 \\ Email: fqiu@stpeters.sa.edu.au
}

Manuscript submitted to The Australian Educational Researcher (AER)

March 2008 


\title{
Globalisation and Chinese Knowledge Diaspora: An Australian Case Study
}

\begin{abstract}
In a context of intensified globalisation factors, knowledge diaspora as "trans-national human capital” has become increasingly valuable to society. With an awareness of a need for more empirical studies especially in Australia, this article concentrates on a group of academics at Monash University who come originally from mainland Chinese to look at their life, work and international research collaborations, using case study approach with semi-structured interviews as the data collection method. It shows while globalisation shapes their work and their contributions to Australia, China and the world, they exert their initiatives to respond to and further reshape globalisation. Equipped with their Chinese cultural and educational backgrounds, academic experience in the West, and active membership in the international knowledge system, the Chinese knowledge diaspora is a modern kind of cosmopolitan literati. They are aware of the impact of globalisation and contribute actively to higher education internationalisation in both Australia and China. They have maintained their cultural identity and made good use of their Chinese background. Their international collaborations, however, are more likely with scholars from Western countries due to some difficulties they have experienced in China and Australia, and to the current setup of the global knowledge system.
\end{abstract}




\section{Globalisation and Chinese Knowledge Diaspora: An Australian Case Study}

\section{Introduction}

Knowledge diaspora is not a new phenomenon. Global knowledge diasporas, however, are a newer phenomenon sustained by both increases in global migration flows, and the rise and increasing ubiquity and density of information and communication technologies (Welch \& Zhang 2007). As a transnational human capital in this new millennium, they become more valuable in a context of fast-increasing geographical mobility and worldwide communication linked to globalisation (Zweig, Chen \& Rosen 2004). There is an urgent need for examining the contributions they make to both their homeland and the new land, and what factors that influence their knowledge work.

Universities provide cross-border educational services and embed themselves deeply in cross-border flows of knowledge workers. The new global cultural economy is a complex, overlapping, disjunctive order (Appadurai 2001), with flows of cultures hardly bounded with nation-states but moving across national boundaries to the global. Within these processes, transnationalism emerges amongst diasporic networks of ethnically and culturally distinctive peoples. The knowledge diaspora is able to interrogate the global through the local and contribute to the creation of "in-between" cultural spaces above the boundary of nation-states (Rizvi, 2000). Universities as a transnational platform where knowledge diaspora work are an essential organisation that creates, transmits, reproduces and receives cultural messages or practices to support the mobility and deployment of the cultural power. While rooted in their own 
cultures and affected by national realities, they are parts of an international knowledge system, and interact with institutions and ideas from abroad.

As knowledge carriers and producers, mobile global talent is a valuable human capital and becomes the priority and target for national policies to strive for. This is because the increase in the stock of brainpower could sustain and increase national economic competency in the knowledge-based economies (Kuptsch \& Pang 2006). The Chinese knowledge diaspora is an important asset to both Australia and China. Australia is small and peripheral in the global economy, due to its relative isolated geographical location, its historical reliance on Britain as a colonial nation and its inadequate population (Hugo 2006). It needs to place stronger emphasis on Asian neighbours. In particular, China is a strong counterpart or partner to provide extraordinary opportunities for Australia (Sutter 2005). Australia's Chinese knowledge diaspora are the most useful and direct human capital for this purpose. However, there has been little research on them, especially in local contexts and in relation to broader axes of spatial relations in state and society (Cartier 2003).

For China, deploying the diaspora option is now a priority, representing a more nuanced response to issues of brain drain (Zweig 2006). From 1978 to 2006, 1,076,000 Chinese students travelled abroad for study purposes. Of these, only 275,000 have returned. While the latest return rate increases fast as more opportunities open up in a dynamic China, the very best and brightest still remains abroad (Cao 2004). They, however, can be seen as a key potential resource, rather than an instance of brain drain. Looking back to China's dramatic development since 1978, the role of Chinese business diaspora has been vital to effectively boost China's 
economy. In a context of globalisation and modern knowledge-based economy, Chinese knowledge diaspora, as a key and underexploited resource (Welch \& Zhang 2007), will play a vital role in China's next stage of development, and accelerate the integration of the Chinese academy into the international knowledge system.

By situating the Chinese knowledge diaspora in a specific local context to investigate their living and working experience, this study aims to reveal how globalisation has shaped the nature of Chinese knowledge diaspora and their academic contributions to both Australia and China, and globally, and how these knowledge diaspora as the subjects of globalisation have exerted their subjective initiatives to respond to and further reshape globalisation. The issues and frustrations confronted by them will be enlightening for a further understanding of the more general situation of the global Chinese knowledge diaspora.

\section{Globalisation, Higher Education and the Chinese Knowledge Diaspora}

Globalisation is a powerful transformative force that has pervaded and dragged more or less sectors of all countries in the world into its global system. It accelerates crossborder mobility of people, capital and knowledge. The flows are guided by the market value and "global profitability" (Burbules \& Torres 2000, p. 9), and influenced by the international hierarchy and power relations. In higher education, the global flows between different nations and institutions are sometimes asymmetrically two-way, sometimes unidirectional (Marginson 2006). The brain drain from poorer countries to the leading institutions in the wealthiest nations certifies that the flow is primarily steered by the economic strength and the capacity of educational and scientific 
systems.

There exists a powerful yet unequal international knowledge system (Altbach 1998), featured by the disparity between North and South. Within its structure, a few countries are the centre retaining extraordinary academic power, while the rest is the periphery and semi-periphery. The lack of well trained academic personnel is a major factor for the peripheral countries to fail to move closer to the centres. The system reveals the stratified nature among cultures, which underlines the fact that flows of intellectuals are still very largely from the South to the North. The existing global inequality of knowledge creation and application is being exacerbated, as wealthy countries of the global North compete to attract research talents from poorer countries of the South (Solimano 2002), whose best and brightest then consolidate the alreadystrong knowledge base in the former (Hugo 2002), at the cost of the latter.

Nevertheless, the non-unilateral, complex, overlapping and unpredictable characteristics of globalisation indicate that the distribution of power is fluid and changing. People who are influenced by globalisation could have both positive and negative impacts on the process, depending on their recognition of globalisation in what respects and on whose terms (Burbules \& Torres 2000). The flows of the highly educated form an increasingly important part of the global knowledge system. Their worldwide circulation could not only consolidate host countries' research hegemony, but also modify global asymmetries and unidirectional transformations (Marginson 2006). The hierarchical structure in knowledge distribution and dissemination has become less fixed, as the loci of power and growth are becoming multiple, and more dispersed (Meyer et al. 2001). The diaspora option can be instrumental in narrowing 
the North-South scientific gap (Meyer \& Brown 1999).

The word diaspora originated from the Greek verb diasperein, meaning to sow or scatter about, and the Greek preposition dia means through or over. The ancient Greeks used it to describe the colonisation of Asia Minor and the Mediterranean in the Archaic period (800-600 BC) (Reis 2004). Diaspora was later used to denote the dispersion of Jews outside of Israel from the $6^{\text {th }}$ century BC, when the Jews were exiled to Babylonia. The word thus connotes the loss of homeland, uprootedness, expulsion, oppression, moral degradation, a collective memory of the homeland and a strong desire to return to it one day. With intensified globalisation, the elements such as the loss of homeland, a collective memory of oppression and the gnawing desire for return have been suppressed, while the positive connotations of diasporas such as super-mobility and flexible identities on the part of transmigrants as well as multiculturalism and transnational flows of capital have been elevated. They now maintain multiple relations-familial, economic, social, organisational, religious, and political-that cross borders (Ma \& Cartier 2003).

The language of diaspora not only advocates the importance of homeland, but also entails fluidity, transnationality and economic-driven characteristics that emphasise the equal importance of hostland and the social transactions between homeland and hostland. The term goes beyond the restriction of narrow and simple identification of persons by traditional ways, which usually refer to nation-state to define people's selfrecognition (Wong 2006). Based on the geographic origins and socioeconomic features of diaspora, we define our research subjects as Chinese knowledge diaspora. The addition of "knowledge" indicates that these diaspora not only has been highly 
educated with at least an undergraduate degree from mainland China before they went overseas, but also are employed currently as knowledge workers and agents of knowledge transfer at university level.

\section{Methodological Considerations}

In social science, reality comes to be understood to human beings only in the form in which it is perceived (Bogdan \& Biklen 2003). All knowledge is socially constructed. Human social life is the aggregate reflection of people's ideas, beliefs, and perceptions that people hold about reality, which are continuously constructed, created, tested, reinforced, and developed by people through their social interaction and response. Research findings are the outcomes produced along with the process by which the investigation proceeds. In order to understand the cultural practice and the meanings assigned to our research subjects, the best way is through their own eyes to open up a range of possible subjects of inquiry (Neuman 2004). The qualitative inquiry allows both our research subjects and us-the researchers-to access the thick descriptions of social life, detailed explanations of social processes, and the generation of theory on both micro and macro levels of analysis (Hesse-Biber \& Leavy 2004).

A case study approach has bee chosen firstly because it allows us to gain an in-depth understanding of the situations and meanings for those involved (Hancock \& Algozzine 2006), locating our target group in their social environment. Secondly, case studies are featured as phenomenon-oriented rather than method-oriented, providing us with flexibility of using various methods and inquiry at different levels to examine 
the case. A case study approach could open the way for us to move towards both meta and micro level investigations, and provide the means for more holistic multidimensional analyses. While this case study is not to develop generalisations, but to seek the particular more than the ordinary (Stake 2005) to understand the case better, we still hope that the analysis of this case sheds light on the general scenario of the Chinese knowledge diaspora around the world.

The choice of Monash University is based on a few reasons. Firstly, a reasonable number of Monash academic staff members are originally from China and have been working there for more than eight years. Secondly, as members of Monash University ourselves at the time of this project, it was relatively easy and convenient for us to access the participants. Thirdly, Monash University is a member of Australia's elite “Group of Eight” and highly internationalised. It has been open to international influences to a greater extent than most Australian universities (Marginson 2000). Its development synchronises with the intensification of globalisation, reflecting the complicated and multi-level influences that globalisation has on higher education.

Our sampling started with a provisional list of Monash’s mainland Chinese academic staff made after sending a global email to invite their expression of interest in participating in this research, in which we elaborated the eligibility criteria that the participants must be originally from China's mainland usually with an undergraduate degree from there, and a minimum of eight years of living overseas. Based on various variables including disciplines, professional ranks, gender and age groups to guarantee less biased and more representative views and perspectives, 15 academics were selected for interviews, as shown in Table 1. 


\begin{tabular}{|c|c|c|c|c|c|c|c|}
\hline Code & Gender & $\begin{array}{l}\text { Age } \\
\text { Group }\end{array}$ & Discipline & $\begin{array}{l}\text { Academic } \\
\text { Rank }\end{array}$ & $\begin{array}{l}\text { Highest } \\
\text { Degree } \\
\text { and Its } \\
\text { Origin }\end{array}$ & $\begin{array}{l}\text { Length } \\
\text { of Stay } \\
\text { in } \\
\text { Australia }\end{array}$ & $\begin{array}{l}\text { Immigration } \\
\text { Status }\end{array}$ \\
\hline M1 & $F$ & $35-40$ & Economics & $\begin{array}{l}\text { Senior } \\
\text { Lecturer }\end{array}$ & $\begin{array}{l}\text { PhD, } \\
\text { Australia }\end{array}$ & 11 years & $\begin{array}{l}\text { Australian } \\
\text { citizen }\end{array}$ \\
\hline M2 & $\mathrm{M}$ & $35-40$ & Economics & $\begin{array}{l}\text { Senior } \\
\text { Lecturer }\end{array}$ & $\begin{array}{l}\mathrm{PhD}, \\
\text { Australia }\end{array}$ & 9 years & $\begin{array}{l}\text { Australian } \\
\text { citizen }\end{array}$ \\
\hline M3 & $\mathrm{M}$ & $41-45$ & Engineering & $\begin{array}{l}\text { Professor } \\
\text { with senior } \\
\text { administrative } \\
\text { roles }\end{array}$ & $\begin{array}{l}\text { PhD, } \\
\text { Australia }\end{array}$ & 18 years & $\begin{array}{l}\text { Australian } \\
\text { citizen }\end{array}$ \\
\hline M4 & $\mathrm{M}$ & $42-45$ & IT & $\begin{array}{l}\text { Associate } \\
\text { Professor, } \\
\text { with senior } \\
\text { administrative } \\
\text { roles }\end{array}$ & $\begin{array}{l}\mathrm{PhD}, \\
\mathrm{UK}\end{array}$ & 12 years & $\begin{array}{l}\text { Australian } \\
\text { citizen }\end{array}$ \\
\hline M5 & $\mathrm{F}$ & $41-45$ & Accounting & $\begin{array}{l}\text { Senior } \\
\text { Lecturer }\end{array}$ & $\begin{array}{l}\mathrm{PhD}, \\
\text { Australia }\end{array}$ & 17 years & $\begin{array}{l}\text { Australian } \\
\text { citizen }\end{array}$ \\
\hline M6 & $\mathrm{M}$ & $41-45$ & Engineering & $\begin{array}{l}\text { Senior } \\
\text { Research } \\
\text { Fellow } \\
\end{array}$ & $\begin{array}{l}\mathrm{PhD} \\
\mathrm{UK}\end{array}$ & 9 years & $\begin{array}{l}\text { Australian } \\
\text { citizen }\end{array}$ \\
\hline M7 & $\mathrm{M}$ & $41-45$ & IT & Lecturer & $\begin{array}{l}\text { PhD, } \\
\text { Australia }\end{array}$ & 8 years & $\begin{array}{l}\text { Australian } \\
\text { permanent } \\
\text { resident }\end{array}$ \\
\hline M8 & M & $41-45$ & $\begin{array}{l}\text { Social } \\
\text { Sciences }\end{array}$ & $\begin{array}{l}\text { Senior } \\
\text { Lecturer }\end{array}$ & $\begin{array}{l}\mathrm{PhD}, \\
\text { UK }\end{array}$ & 15 years & $\begin{array}{l}\text { Australian } \\
\text { citizen }\end{array}$ \\
\hline M9 & $\mathrm{F}$ & $41-45$ & $\begin{array}{l}\text { Business } \\
\text { and } \\
\text { Economics }\end{array}$ & $\begin{array}{l}\text { Associate } \\
\text { Professor }\end{array}$ & $\begin{array}{l}\text { PhD, } \\
\text { Australia }\end{array}$ & 15 years & $\begin{array}{l}\text { Australian } \\
\text { citizen }\end{array}$ \\
\hline M10 & $\mathrm{M}$ & $46-50$ & $\begin{array}{l}\text { Health } \\
\text { Sciences }\end{array}$ & $\begin{array}{l}\text { Associate } \\
\text { Professor }\end{array}$ & $\begin{array}{l}\mathrm{PhD}, \\
\text { Australia }\end{array}$ & 19 years & $\begin{array}{l}\text { Australian } \\
\text { citizen }\end{array}$ \\
\hline M11 & $\mathrm{M}$ & $46-50$ & $\begin{array}{l}\text { Health } \\
\text { Sciences }\end{array}$ & $\begin{array}{l}\text { Associate } \\
\text { Professor }\end{array}$ & $\begin{array}{l}\text { PhD, } \\
\text { France }\end{array}$ & 14 years & $\begin{array}{l}\text { Australian } \\
\text { citizen }\end{array}$ \\
\hline M12 & $\mathrm{M}$ & $51-55$ & Engineering & $\begin{array}{l}\text { Professor, } \\
\text { with senior } \\
\text { administrative } \\
\text { roles }\end{array}$ & $\begin{array}{l}\mathrm{PhD}, \\
\mathrm{UK}\end{array}$ & 15 years & $\begin{array}{l}\text { Australian } \\
\text { citizen }\end{array}$ \\
\hline M13 & $\mathrm{M}$ & $51-55$ & Humanities & $\begin{array}{l}\text { Senior } \\
\text { Lecturer }\end{array}$ & $\begin{array}{l}\mathrm{PhD}, \\
\text { Australia }\end{array}$ & 20 years & $\begin{array}{l}\text { Australian } \\
\text { citizen }\end{array}$ \\
\hline M14 & $\mathrm{F}$ & $56-60$ & Management & $\begin{array}{l}\text { Associate } \\
\text { Professor, } \\
\text { with senior } \\
\text { administrative } \\
\text { roles }\end{array}$ & $\begin{array}{l}\text { PhD, } \\
\text { Australia }\end{array}$ & 17 years & $\begin{array}{l}\text { Australian } \\
\text { citizen }\end{array}$ \\
\hline M15 & $\mathrm{M}$ & $56-60$ & Finance & Lecturer & $\begin{array}{l}\text { PhD, } \\
\text { Australia }\end{array}$ & 17 years & $\begin{array}{l}\text { Australian } \\
\text { citizen }\end{array}$ \\
\hline
\end{tabular}

Our data were collected through semi-structured interviews which allowed us to enter into the interviewees' “inner perspectives” (Patton 2002), and provided us with 
opportunities to interactively link with them to make sense of what they reflected on in relation to their feelings, thoughts, intentions and behaviours that had taken place at some previous point in time. It also allowed us to observe, in addition to asking and listening, encourage our interviewees to fully express their understanding, and better understand their viewpoints by looking at their actions and facial expressions.

Fifteen interviews were conducted. Except for one interview, all were tape-recorded. As to the one that was not tape-recorded, we asked for permission to take notes. The length of the interviews was flexible depending on the extent of exploration the interviewee engaged in, with an average of 50 minutes. All interviews were conducted in Chinese Mandarin. The use of mother tongue could eliminate misunderstandings to the greatest extent and deepen the comprehension of issues because language is more than a means of communication about reality. Indeed, it is a tool for constructing reality (Spradley, 1979).

After conducting interviews, the tape-recorded individual interviews and notes were transcribed and categorised according to our research questions. The draft "analytical categories” with detailed descriptions were the basis for coding. Grounded theory was applied. Based on the "material” (Schmidt 2000), the concepts and themes and how they were linked to each other and to the existent knowledge were identified successively.

\section{Major Findings}

In consideration of the unique features of the Chinese knowledge diaspora and based 
on the data we collected from our interviews, we present the following major findings.

\section{Self Identity}

In terms of how the Chinese knowledge diaspora identify themselves and how their self-identity affects their life and work at Monash and their international collaboration especially with China, there is a clear agreement among all the participants that mainland Chinese is part of their self-identity. The degree of such recognition varies for a number of reasons, from the time spent in China and Australia, family and children to the intensity of connecting to China. Most of the characteristics of diasporas such as dispersion, supermobility and memories of the homeland were mentioned by the participants, while political exile was strongly rejected.

As to how the mainland Chinese knowledge diaspora settle in Australia and whether or not they feel alienated, all our participants felt cultural integration was the most difficult for them. None of them thought they had been fully integrated into the Australian mainstream society, although they felt comfortable and confident at work. According to M7, full integration was impossible. M15 borrowed his son’s experience and guessed the possibility for the third-generation. One participant insisted that he would never be integrated into the mainstream Australian society. Two questioned the term Australian mainstream society. Most of them, however, admitted that they were partially integrated. Although sometimes they complained about their work and life in Australia, they were largely happy and comfortable with their current situation, and did not think the issue of integration was significant enough to affect their living and working. 
Australia's multicultural social environment provides possibilities for the participants. The diverse ethnic communities moderate the hegemonic Anglo-Australian impression in people's minds. With the expanding Chinese population in Australia, although they do not necessarily feel they have been fully integrated into the mainstream society, other people view their scholars' social status as a sign of being part of the mainstream, as mentioned by M15. Meanwhile, as modern professionals with sufficient English competency, they are networking with both Chinese and nonChinese. As expressed by M4, "I did not pay attention to this issue because I have both Chinese and non-Chinese friends.”

The responses from the Monash Chinese knowledge diaspora challenge the notion that migrants from China are not able to embrace an alternative environment, due to their lack of genuine interest in Australia and the totalitarian Chinese society (Gilbert et al. 2000). The feeling of alienation in the host country was not particularly significant among our participants. In contrast, after living and working overseas for years, with knowledge acquired from both Chinese and Western societies, they have created ways to enact individualism and combine Chinese spiritual tradition with secular Western knowledge (Wang 2001), and have become a modern kind of cosmopolitan literati that have a great deal to offer to Australia, China and the world.

\section{Influences of Chinese Background}

Except for one participant who had only his first year of tertiary education in China before going overseas, the others all completed their undergraduate education in 
China, several went overseas after obtaining their Master's degrees. Most of them identified both advantages and disadvantages caused by their Chinese educational background. Two considered their Chinese education background as a disadvantage, and thought it might have contributed to their relatively low academic rank at Monash. The majority, however, viewed it as beneficial to their work, even helped them with their job acquisition and professional development. As M5 illustrated, her Chinese background placed her in a wining position when she competed with others for her post at Monash. M13 detailed how his Chinese connections facilitated him to build up in-country programs with China, which brought both financial and social benefits to his department. Five participants (M2, M12, M10, M8 and M11) acknowledged implicitly the contribution of their previous learning and working experience in China to their innovative thinking.

China's recent development brings benefits to them, especially those in economics and management. As M1 explained, the advancement of Chinese economy has made many China-related economic issues more interesting and relevant to the international community. M3 noted the increasing attention paid by Monash to developing collaborative programs with China because of China's development. With the number of international students from Chinese cultural background fast increasing at Monash, some participants mentioned they are better placed to communicate with such students than their colleagues from non-Chinese backgrounds.

It is interesting to note that traditional Chinese virtues such as having persistence in the face of adversity and striving for a juste-milieu are regarded as a double-edged sword: while being hardworking and bearing tough times motivated them to achieve 
academic success, they contradicted with the mainstream Australian values, such as enjoying life and projecting oneself, and even restricted their personal development.

There are some other perceived disadvantages, including weak English proficiency, inadequate knowledge of local culture and customs, and difficulties in networking in the international Western-dominated academic community. The lack of English proficiency was mentioned by every interviewee. As the native language of the two modern hegemonic powers, English dominates the global academy. Compared with native English speakers, the Chinese knowledge diaspora often struggle with the language and its related culture, although the threat is much less for those in hard sciences.

\section{Research Collaborations with China}

Previous studies have shown that cultural and linguistic backgrounds contribute to closer scholarly communications. Among intellectual diasporas, there is a strong sentiment regarding a willingness to cooperate with the home country (Meyer et al. 2001). Choi (1995) also observes that many Asian background academics in American higher education keep close contact with their countries of origin, maintaining scientific and academic relationships with colleagues and institutions at home. Considering their Chinese background and their social and academic networks in China, one general assumption is that Chinese knowledge diaspora would work particularly well in their research collaboration with China.

Our research, however, has found that although all the participants expressed their 
interest in research collaboration with China and have maintained contacts with their friends, family and colleagues there, real collaboration in research and teaching has been limited: among the 15 interviewees, 4 had no concrete research collaboration; 8 had less than half of their collaborative research projects with China; 3 had formal and concrete collaborative research programs with China. The intensity, frequency, consistency and effectiveness of collaborations with China were not significant. The establishment of research collaboration with China requires more than passion. Indeed, it was affected by various factors at multiple levels, which are often out of the control of them.

The three participants with substantial research collaborations with China shared some common features: a clear awareness of the importance and benefit of such collaborations, their love for China, and their eagerness to contribute to its development. M11, for example, with his first collaboration with his Alma Mater solely driven by his passion for China, he has won a project funded by the prestigious Chinese Natural Science Foundation (NSF), and has snowballed his collaboration. M12's story is similar, and is happy with his achievements: "The outcomes after 5year 'incubation’ were fruitful and beyond my expectation. Since then, my research collaboration with China has been well developed.” Although M8 has just been employed by Monash, he has started collaborations with a Chinese university to compile a textbook for Chinese undergraduate students, with an application for a NSF project high on his agenda.

Their previous academic networks in China have an effective role to play in stimulating research collaborations, especially since the 1990s when China started to 
accelerate the integration of its scholarly circle into the international community. The Chinese intellectual diaspora are an ideal agent to liaison Chinese and Western academic communities, and assist mainland China scholars to enter into the global knowledge system by joint projects and publications in international mainstream journals. This was repeatedly confirmed by a number of participants generally, and by M6 in particular. Such knowledge bridges are in part responsible for China’s rapidly rising scientific stature (Li, 2005).

As more and more Chinese students coming to Australia to read for higher degrees, the diaspora have extended their collaboration from their former teachers and fellow students in China to the returned students they have supervised overseas. M8, for example, works with his former students who returned to China and have since become established scholars there. Their collaborations have been strongly supported by M8's former schoolmates who are now senior university administrators. M4 also illustrated this using his own experience as an example.

Some participants started their collaborative research projects as the result of the internationalisation of their faculties or the university. For instance, M5 has a few China-related research projects which are parts of a much larger project of her faculty. M1 also benefited from the existing scholar exchange program run at her faculty. She has been working collaboratively with visiting scholars from China. The stories of these participants confirm Monash University's commitment to internationalisation, and illustrate that the diaspora could act as an agent to create new and different forms of international education in the globalisation of higher education. Both they and their university benefit from each other in such activities. 
The picture, however, is not always as rosy. While every participant expressed his/her interest in conducting collaborative research with China, a number of factors restrict the fulfilment of such a good will. The most prominent is financial difficulties on both sides, as illustrated by M13. Other restrictive factors include heavy workload, excessive accountability, and divergent research priorities in the two countries that have made some participants flinch from developing research collaborations with China. Both M2 and M7 did not want to add anything more to their workload. Some respondents such as M10 and M13, although aware of Monash’s emphasis on collaboration with China, feel that Monash does not regard them highly as a reliable agent or strength in the promotion of internationalisation.

\section{Differences between Collaborations with Chinese and Other Partners}

Interestingly, the Chinese knowledge diaspora collaborate more with scholars from other countries than China. Their partners are more likely from Western and a few well developed Asian countries. A number of reasons were listed by our participants, all of which related to the differences between collaborating with Chinese and other partners. The Chinese diaspora communicate and collaborate with Chinese and other partners in the same way. The difference lies in the emotional aspect of the knowledge diaspora who often feel closer to other Chinese scholars. Their collaborations thus include cultural elements. Much collaboration is deeply rooted in personal relationships.

However, our participants suggested that such friendships or guanxi could also be 
developed through longstanding collaboration with scholars from non-Chinese cultures. M2, for example, pointed out that guanxi was important almost everywhere, and scholars from other societies emphasised guanxi as well. M8 agreed, and went further by saying "Westerners also considered guanxi a lot, but their guanxi is different. Chinese guanxi emphasises self-interest. In order to build up guanxi in China, you need to deliver benefits or gifts. In contrast, building up guanxi and mutual trust with Westerners is often through collaborative work and common research interests.”

Another common difficulty expressed by them in their collaboration with China was the lack of funding and unavailability of important research data. M3, M6 and M10 all felt that it was much easier to gain funding from industrialised Western countries. Our participants from a variety of disciplines at all academic ranks reported that insufficient funding from the Chinese side was a common issue that had affected their collaboration with China, particularly in the areas of medicine, IT, engineering and health sciences. Despite that some such as M8 and M6 acknowledged their willingness to contribute to China unconditionally others including M4 and M12 stressed the mutual benefits as the most important factor for their collaborations.

Most participants highlight the fact that their Chinese partners emphasised personal gains too much is the reason why the collaboration in basic research has been highly limited. Confirmed by M8 and M13, M3 recalled his experience of collaboration and remarked: "We must invest money and let them (Chinese collaborators) see the benefits. The tendency of earning money is becoming stronger and stronger. Everything is for money.” 
Apart from funding, some participants reported their difficulties in obtaining data from China. This is a particularly serious problem for those in the social sciences. M9 whose area is economics said she could not conduct any China-related research without sufficient data support. Very often some data are not released publicly in China.

The quality of their Chinese partners is another important factor that affects their collaboration. Most of our participants reported the poor quality of their Chinese partners. The most frequently mentioned limitations included insufficient English proficiency, poor research training, limited knowledge of the international literature, and lack of familiarity with the international practice in the scholarly community such as the commonly accepted codes of conduct.

Related to the lack of international practice is a striking shortage of genuine motivation for research among Chinese academics. M9 mentioned she was invited a year ago by a top Chinese university to lecture there for three weeks. According to her, "the professors especially the established ones were not interested in research at all, they were so busy with participating in profit-making activities.” Such an observation concurs with the findings of other studies (Yang 2005).

Despite all the difficulties, it remains a common understanding among our participants that collaboration with China is not only what they want but also what they need. As M2 acknowledged, collaborating with China have broadened his perspective. Indeed, they have all benefited from this, as knowledge workers in 
Australia.

The collaboration is not only emotionally appropriate, but also politically and economically correct. There appears to be an international competition for Western universities to work with China. Several interviewees expressed that they had found it increasingly hard to conduct research collaborations with China. As M5 said, "In the early 1990s, any overseas scholars were welcomed unconditionally. Now, China’s standards for choosing overseas partners have become higher and higher.”

\section{Conclusions}

The global circulation of epistemic currents, including among diasporic communities, challenges our longstanding notion of space and place (Tsolidis 2001). Diasporic intellectuals and the trans-national networks they establish, as part of the wider phenomenon of increased global mobility undergirded by greater density and diffusion of information technology, could tilt the balance towards countries such as China and create far more complex and decentralised, two-way flows of knowledge. The exodus of the highly skilled could be both a loss and a potential gain for the country of origin (Lowell \& Gerova 2006; Wickramasekara 2002).

Our examination of the Chinese knowledge diaspora and their research collaborations in a context of globalisation at the specific setting of Monash University shows that they have in general played different roles. While they are just like other Monash academic staff members shouldering their daily teaching and research responsibilities, they are often initiators and active participators of Monash's internationalisation 
programs with China. They continue to disseminate Chinese culture in all possible occasions, and always adjust themselves to integrate different cultures and values into their own teaching and research.

This group has never stopped contributing to China's development in various forms and shapes. Originally from mainland China with posts in a system that is better positioned in the global network (Altbach 1998), they are indeed the brain power stored overseas. They not only help mainland scholars enter into the international knowledge system, but also maintain broad contacts with other scholars in the world and conduct various international research collaborations. They thus play a unique role to link China more closely to the international scholarly community. In this sense, their stories endorse China’s policies to encourage free movement of Chinese knowledge diaspora to and from China to serve China's development in various ways.

There are, however, a number of restrictions at different levels that counteract the effects of their research collaboration with China ranging from their daily heavy workload, excessive accountability system, to the difficulty in gaining funding from both Australia and China, suggesting the influence of the neo-liberal globalisation and its related entrepreneurialism and academic capitalism on the higher education systems in both countries. Against such a backdrop, not every Chinese knowledge diaspora at Monash has expressed clear intention to act against the negative influence of globalisation. Indeed, some of them choose to compromise. Relatively, Chinese academics appear to be influenced by globalisation even more profoundly, and the traditional academic values are at risk in their relentless pursuit of money (Yang, 2005). This has direct impact on their collaborations with the Chinese knowledge 
diaspora.

Despite all the difficulties, the belief in the significance of such collaborations remains, even further enhanced on the basis of the Chinese knowledge diaspora's strong passion for China, and of the fact that China is emerging as a global power. More generally, our case study demonstrates the special value of diaspora scholars who have travelled widely and experienced different cultures and intellectual traditions. They are a particularly important asset within a context of intensified globalisation, and thus deserve a better treatment than what they have usually received.

\section{References}

Altbach, P. G. (1998) Comparative Higher Education: Knowledge, the University and Development, Ablex Publishing Corporation, London.

Appadurai, A. (2001) Grassroots globalisation and the research imagination, in A. Appadurai, ed., Globalisation, Duke University Press, Durham.

Bogdan, R. C., and Biklen, S. K. (2003) Qualitative Researchj for Education: An Introduction to Theory and Methods, Pearson Education, Boston.

Burbules, N. C. and C. A. Torres, eds. (2000) Globalisation and Education: Critical Perspectives, Routledge, New York.

Cao, C. (2004) Chinese science and the "Nobel Prize" complex, Minerva, vol. 42, no. 2, pp. 151-72.

Cartier, C. (2003) Regions of diaspora, in J. C. L. Ma and C. Cartier, eds. The Chinese Diaspora: Space, Place, Mobility, and Identity, Rowman \& Littlefield, 
Lanham, MD.

Choi, H. (1995) An International Scientific Community: Asian Scholars in the United States, Praeger, New York.

Gilbert, H., Khoo, T., and J. Lo, eds. (2000) Diaspora: Negotiating Asian-Australia, University of Queensland Press, St. Lucia, Queensland.

Hancock, D. R., and Algozzine, B. (2006) Doing Case Study Research: A Practical Guide for Beginning Researchers, Teachers College Press, New York.

Hesse-Biber, S. N. and P. Leavy, eds. (2004) Approaches to Qualitative Research. Oxford University Press, New York.

Hugo, G. (2002) Migration policies designed to facilitate the recruitment of skilled workers in Australia, in OECD, ed. International Mobility of the Highly Skilled, OECD, Paris.

Hugo, G. (2006) Australian experience in skilled migration, in C. Kuptsch and E. F. Pang, eds. Competing for Global Talent, International Institute for Labour Studies, Geneva.

Kuptsch, C. and E. F. Pang, eds. (2006) Competing for Global Talent, International Institute for Labour Studies, Geneva.

Li, P. (2005) Immigration from China to Canada in the age of globalization: Issues of brain drain and brain loss. Paper presented at People on the Move: The Transnational Flow of Chinese Human Capital, Hong Kong University of Science and Technology, Hong Kong, October.

Lowell, L. and Gerova, S. (2006) Diasporas and Economic Development: State of Knowledge, Institute for the Study of International Migration, Georgetown University, Washington D.C.

Ma, L. J. C. and C. Cartier, eds. (2003) The Chinese Diaspora: Space, Place, Mobility, 
and Identity, Rowman \& Littlefield, Lanham, MD.

Marginson, S. (2000) Monash: Remaking the University, Allen \& Unwin, Sydney.

Marginson, S. (2006) Dynamics of national and global competition in higher education, Higher Education, vol. 52, no. 1, pp. 1-39.

Meyer, J-B. and Brown, M. (1999) Scientific diasporas: A new approach to the brain drain. Paper presented at the World Conference on Science. UNESCO ICSU, Budapest, June.

Meyer, J-B., Kaplan, D. and Caran, J. (2001) Scientific Nomadism and the New Geopolitics of Knowledge, UNESCO, Oxford.

Neuman, W. L. (2004) Basics of Social Research: Qualitative and Quantitative Approaches, Pearson Education, Boston.

Patton, M. (2002) Qualitative interviewing, in M. Patton, ed. Qualitative Research and Evaluation Methods, Sage, Thousand Oaks.

Reis, M. (2004) Theorising diaspora: perspectives on "classical" and "contemporary" diaspora, International Migration, vol. 42, no. 2, pp. 41-60.

Rizvi, F. (2000) International education and the production of global imagination, in N. Burbules and C. Torres, eds. Globalisation and Education: Critical Perspectives, Routledge, London.

Schmidt, C. (2000) The analysis of semi-structured interviews, in U. Flick, E. V. Kardorff and I. Steinke, eds. A Companion to Qualitative Research, Sage, Thousand Oaks.

Solimano, A. (2002) Globalising Talent and Human Capital: Implications for Developing Countries, UN, Santiago.

Spradley, J. P. (1979) The Ethnographic Interview, Holt, Rinhart and Winston, New York. 
Stake, R. (2005) Qualitative case studies, in N. Denzin and Y. Lincoln, eds. The SAGE Handbook of Qualitative Research (3rd edition), Sage, Thousand Oaks.

Sutter, R. G. (2005) China's Rise in Asia: Promises and Perils, Rowman \& Littlefield, Lanham, MD.

Tsolidis, G. (2001) Schooling, Diaspora and Gender, Open University Press, Buckingham.

Wang, G. (2001) Don't Leave Home: Migration and the Chinese, Times Academic Press, Singapore.

Welch, A. R., and Zhang, Z. (2007). The rise of the Chinese knowledge diaspora: Possibilities, problems and prospects for South and North. Paper presented at the World University Network Forum Realising the Global University, London, 14-15 November.

Wickramasekara, P. (2002) Policy Response to Skilled Migration: Retention, Return and Circulation, International labour Organisation, Geneva.

Wong, B. P. (2006) The Chinese in Silicon Valley, Rowman \& Littlefield, Lanham, MD.

Yang, R. (2005) The Chinese professoriate in comparative perspective: Selfperceptions, academic life, gender differences and internal differentiation, in A. R. Welch, ed. The Professors: Profile of a Profession, Springer, Dordrecht.

Zweig, D. (2006) Learning to compete: China's efforts to encourage a "reverse brain drain,” in C. Kuptsch and E. F. Pang, eds. Competing for Global Talent, International Institute for Labour Studies, Geneva.

Zweig, D., Chen, C., and Rosen, S. (2004) Globalisation and transnational human capital: overseas and returnee scholars to China, The China Quarterly, vol. 179, pp. 735-57. 